\title{
PENGARUH MODEL PEMBELAJARAN CHILDREN LEARNING IN SCIENCE BERBASIS BUDAYA PENYELIDIKAN TERHADAP KOMPETENSI PENGETAHUAN IPA
}

\author{
Ni Putu Mia Astiti \\ Jurusan Pendidikan Guru Sekolah Dasar, Universitas Pendidikan Ganesha \\ E-mail:miaastiti@gmail.com \\ I Ketut Ardana \\ Jurusan Pendidikan Guru Sekolah Dasar, Universitas Pendidikan Ganesha \\ Email: ketut_ardana55@yahoo.co.id \\ I Wayan Wiarta \\ Jurusan Pendidikan Guru Sekolah Dasar, Universitas Pendidikan Ganesha \\ E-mail: wayanwiarta.63@gmail.com
}

\begin{abstract}
Abstrak
Penelitian ini bertujuan untuk mengetahui pengaruh model pembelajaran children learning in science berbasis budaya penyelidikan terhadap kompetensi pengetahuan IPA siswa kelas V SD Gugus Srikandi Denpasar Timur. Penelitian ini termasuk penelitian eksperimen semu dengan desain non-equivalent control group design. Populasi dalam penelitian adalah seluruh siswa kelas V di SD Gugus Srikandi Denpasar Timur tahun pelajaran 2016/2017 yang berjumlah 344 siswa. Sampel penelitian ini ditentukan dengan teknik random sampling. Data hasil kompetensi pengetahuan IPA dikumpulkan dengan menggunakan tes objektif tipe pilihan ganda biasa yang dianalisis dengan menggunakan teknik analisis statistik deskriptif dan statistik inferensial dengan uji-t. Berdasarkan hasil analisis diperoleh thitung $=3,95$ dengan $\mathrm{dk}=67 \mathrm{dan}$ taraf signifikansi $5 \%$ diperoleh $t_{\text {tabel }}=2,00$. Dengan demikian, nilai thitung $>t_{t a b e l}$. Selain itu, nilai rata - rata kompetensi pengetahuan IPA siswa yang dibelajarkan melalui model pembelajaran children learning in science berbasis budaya penyelidikan lebih dari rata - rata siswa yang tidak dibelajarkan melalui model pembelajaran children learning in science berbasis budaya penyelidikan yakni $(80,51>71,03)$. Dengan demikian, model pembelajaran children learning in science berbasis budaya penyelidikan berpengaruh terhadap kompetensi pengetahuan IPA siswa kelas V SD Gugus Srikandi Denpasar Timur tahun pelajaran 2016/2017.
\end{abstract}

Kata kunci: children learning in science, budaya penyelidikan, kompetensi pengetahuan IPA

\begin{abstract}
This research aimed to know the effect of learning model of children learning in science based on a culture of inquiry of competence knowledge of science at the students grade V of SD Gugus Srikandi East Denpasar. This research included quasi-experimental research with non-equivalent control group design. The population were all students grade V in SD Gugus Srikandi East Denpasar academic year 2016/2017 which consists of 344 students. The sample of this research was taken by using random sampling technique. Data on competence knowledge of science were collected by using the usual double choice type objective test which was analyzed by using descriptive statistical analysis and inferential statistic with t-test. Based on the results obtained $t_{\text {count }}=3,95$ with $\mathrm{dk}=67$ and $5 \%$ significance level obtained table $=2,00$. That meant, the value of tcount $>$ table. In addition, the mean score competence knowledge of science who were taught by learning model of children learning in science based on a culture of inquiry is more than the mean of students who were not taught by learning model of children learning in science based on a culture of inquiry $(80,51>71,03)$. Thus, can concluded that the learning model of children learning in science based on a culture of inquiry have an effect to the competence knowledge of science students grade V of SD Gugus Srikandi East Denpasar in academic year 2016/2017.
\end{abstract}

Keywords : children learning in science, culture of inquiry, competence knowledge of science

\section{Pendahuluan}

Pendidikan merupakan proses kehidupan yang dialami dan harus dilaksanakan sepanjang hidup. Setiap orang berkewajiban untuk mengembangkan diri. Pengembangan diri ini terutama diarahkan untuk memberikan bekal kompetensi yang dapat dijadikan sebagai sarana untuk menghadapi hidup. Melalui proses pendidikan, akan terbentuk sumber daya manusia yang berkualitas.

Adapun jenjang dalam penyelenggaraan pendidikan, salah satunya adalah jenjang sekolah dasar (SD). Pendidikan di SD merupakan jenjang pendidikan dasar yang berfungsi sebagai peletakan dasar - dasar keilmuan dan membantu mengoptimalkan perkembangan siswa melalui pembelajaran yang dibimbing oleh 
guru sehingga mampu membina siswa menjadi manusia paripurna, dewasa, dan berbudaya (Susanto, 2013). Tujuan dari pendidikan di SD adalah agar siswa mampu memahami potensi diri, peluang dan tuntutan lingkungan serta merencanakan masa depan melalui pengambilan serangkaian keputusan yang mungkin bagi dirinya. Oleh karena itu, pengelolaan dan peningkatan mutu pendidikan sangat diperlukan.

Salah satu upaya yang dilakukan untuk meningkatkan mutu pendidikan adalah dengan diadakannya perubahan kurikulum. Menurut Undang - Undang Nomor 20 Tahun 2003 tentang Sistem Pendidikan Nasional Pasal 1 Ayat 19 mendefinisikan kurikulum adalah "seperangkat rencana dan pengaturan mengenai tujuan, isi, dan bahan pelajaran serta cara yang digunakan sebagai pedoman penyelenggaraan kegiatan pembelajaran untuk mencapai tujuan pendidikan tertentu". Dalam dunia pendidikan, kurikulum mempunyai kedudukan yang cukup sentral karena menentukan proses pelaksanaan dan hasil pendidikan. Kurikulum 2013 yang sudah mulai diterapkan di Indonesia saat ini merupakan penyempurnaan Kurikulum Berbasis Kompetensi (KBK) yang telah dirintis pada tahun 2004 dan Kurikulum Tingkat Satuan Pendidikan (KTSP) yang sudah diterapkan sejak tahun 2006. Pendidikan selama ini dianggap belum mampu menghasilkan sumber daya manusia yang profesional secara akademik dan tangguh secara karakter sehingga dikembangkankanlah kurikulum 2013. Namun saat ini, pengimplementasian kurikulum 2013 masih menemui berbagai kendala, sehingga belum dapat diterapkan di seluruh wilayah yang ada di Indonesia.

Pembelajaran pada kurikulum 2013 menggunakan pendekatan saintifik. Pendekatan saintifik dalam pembelajaran meliputi kegiatan mengamati, menanya, mengumpulkan informasi/mencoba, mengasosiasi/menalar, dan mengomunikasikan. Proses pembelajaran kurikulum 2013 diarahkan menjadi pembelajaran yang berpusat pada siswa (student centered) tidak lagi didominasi oleh guru (teacher centered) yang cenderung membosankan. Pendekatan saintifik dimaksudkan untuk memberikan pemahaman kepada siswa dalam mengenal dan memahami berbagai materi menggunakan pendekatan ilmiah. Informasi yang diterima dapat berasal dari mana saja, kapan saja, tidak hanya bergantung pada guru (Kurniasih dan Berlin, 2014).

Salah satu muatan materi yang terintegrasi dalam pembelajaran adalah Ilmu Pengetahuan Alam (IPA), yang sering disebut juga dengan istilah pendidikan sains. "IPA merupakan terjemahan kata - kata dalam bahasa Inggris yaitu natural science. Berhubungan dengan alam atau bersangkut paut dengan alam" (Samatowa, 2016:3). Menurut Wisudawati dan Eka (2015:22) IPA merupakan "rumpun ilmu yang memiliki karakteristik khusus yaitu mempelajari fenomena alam yang faktual, baik berupa kenyataan atau kejadian dan hubungan sebab akibatnya". Jadi dapat dsimpulkan, IPA merupakan ilmu yang mempelajari peristiwa - peristiwa yang terjadi di alam ini.

Pembelajaran muatan materi IPA di SD hendaknya membuka kesempatan untuk memupuk rasa ingin tahu siswa secara alamiah, mengembangkan kemampuan mencari jawaban berdasarkan bukti yang ditemukan dan mengembangkan cara berpikir ilmiah. Muatan materi IPA berisikan hafalan dan konsep, maka dari itu siswa harus diberi kesempatan untuk mengembangkan sikap ingin tahu dan berbagai penjelasan logis. Sering kali dalam kegiatan pembelajaran, siswa memiliki konsep yang keliru mengenai suatu hal, sehingga penting bagi guru untuk membuat siswa mengerti tentang konsep yang dipelajarinya. Wisudawati dan Eka (2015) menyatakan bahwa muatan materi dalam IPA mempelajari fenomena - fenomena alam dan memerlukan penalaran lebih oleh siswa. Karakteristik muatan materi IPA yang cenderung abstrak akan menuntut guru untuk berinovasi dalam merumuskan model pembelajaran yang tepat untuk menyampaikannya. Lebih lanjut, Susanto (2013:93) mengemukakan bahwa "guru harus mampu merancang model pembelajaran yang bermakna bagi siswa. Untuk itu, guru harus kreatif dalam mendesain model pembelajaran yang memungkinkan siswa dapat berpartisipasi, aktif, kreatif terhadap materi yang diajarkan".

Berdasarkan hasil observasi yang telah dilaksanakan pada tanggal 29 Desember 2016 dan 4 Januari 2017 di enam SD negeri yang ada di Gugus Srikandi Denpasar Timur tahun pelajaran 2016/2017 terdapat temuan yaitu konsep IPA yang dipelajari kurang dikaitkan dengan kehidupan sehari - hari sehingga konsep tersebut terasa abstrak dan pembelajaran terkesan kurang bermakna bagi siswa. Model pembelajaran yang diterapkan oleh guru dalam kegiatan pembelajaran kurang variatif. Selain itu antusias siswa dalam proses pembelajaran masih kurang karena muatan materi IPA berisikan hafalan dan konsep, siswa lebih senang bercanda dengan temannya. Dengan demikian, hal tersebut berpengaruh terhadap kompetensi pengetahuan IPA yang ditetapkan oleh sekolah.

Sebagai langkah dalam menciptakan pembelajaran yang bermakna bagi siswa, maka dalam penelitian ini dicobakan salah satu inovasi pembelajaran yaitu dengan menggunakan model pembelajaran children learning in science berbasis budaya penyelidikan. Dalam pelaksanaannya model pembelajaran children learning in science, siswa melakukan percobaan atau observasi, dengan didasarkan pada budaya penyelidikan. 
Model pembelajaran children learning in science merupakan salah satu model pembelajaran yang dilandasi oleh pandangan konstruktivis dengan memperhatikan dan mempertimbangkan pengetahuan awal siswa yang mungkin diperoleh di luar sekolah. Melalui kegiatan pembelajaran dari model pembelajaran children learning in science, Samatowa (2016:76) mengemukakan bahwa "siswa yang konsepsi awalnya tidak konsisten dengan konsep ilmiah sadar akan mengubah konsepsi awalnya menjadi konsep ilmiah". Oleh karena itu, dalam kegiatan pembelajaran siswa tidak hanya diberikan hafalan dan penekanan pada penguasaan konsep semata tetapi juga diberikan kesempatan untuk mengembangkan sikap ingin tahu melalui percobaan atau observasi.

Penyelidikan mengacu pada proses intelektual yang telah dilakukan oleh manusia selama ribuan tahun. National Science Education Standards (dalam Sarwiji, 2013:46) menyatakan bahwa penyelidikan ilmiah mengacu pada berbagai macam cara yang dipakai ilmuwan, untuk mempelajari alam dan mengungkapkan penjelasan berdasarkan bukti yang mereka peroleh dari proses itu. Penyelidikan juga mengacu pada aktivitas yang dilakukan siswa untuk mengembangkan pengetahuan dan pemahaman mengenai gagasan - gagasan ilmiah, serta pemahaman mengenai bagaimana ilmuwan mempelajari alam. Pembelajaran dengan berbasis pada budaya penyelidikan dapat memberi kesempatan untuk melibatkan siswa yang tertarik pada penelitian ilmiah, mempertajam kemampuan berpikir kritis, dan meningkatkan kesadaran akan pentingnya riset mendasar (Sarwiji, 2013).

Berkaitan dengan hal tersebut, model pembelajaran children learning in science dapat dikembangkan dan dipadukan dengan budaya penyelidikan. Budaya penyelidikan adalah pola sikap yang menjadi cara atau pedoman yang digunakan untuk menggali, menjelaskan dan mengenal sesuatu (Nalasari, 2016). Sehingga dapat disimpulkan, model pembelajaran children learning in science berbasis budaya penyelidikan merupakan kegiatan pembelajaran yang mendorong siswa untuk mampu memahami, menemukan dan merekonstruksi konsep yang sedang dipelajari dan didasarkan pada pengembangan cara menyelidiki agar pembelajaran menjadi bermakna.

Pembelajaran muatan materi IPA di SD yang dilakukan dengan penyelidikan dan bukan hafalan akan berdampak positif terhadap kompetensi pengetahuan siswa, karena saat proses pembelajaran siswa mendapat pengalaman langsung melalui observasi, diskusi, dan penyelidikan. Siswa akan belajar untuk menemukan dan menanamkan pemahaman konsep kemudian mengaplikasikannya untuk memecahkan masalah yang dijumpai siswa dalam kehidupan sehari - hari. Dengan pemahaman konsep yang benar dapat membuat konsep yang diajarkan tidak akan mudah dilupakan, siswa juga tidak mengalami kebingungan sehingga akan dapat menunjang pencapaian kompetensi pengetahuan IPA siswa menjadi lebih optimal.

Samatowa (2016) menyatakan model pembelajaran children learning in science terdiri atas lima langkah utama, yakni orientasi (orientation), pemunculan gagasan (elicitation of ideas), penyusunan ulang gagasan (restructuring of ideas), penerapan gagasan (application of ideas), dan pemantapan gagasan (review change in ideas). Langkah penyusunan ulang gagasan (restructuring of ideas) masih dibedakan atas tiga bagian, yaitu pengungkapan dan pertukaran gagasan (clarification and exchange), pembukaan pada situasi konflik (exposure to conflict situation), dan konstruksi gagasan baru dan evaluasi (construction of new ideas and evaluation).

Dalam pembelajaran model pembelajaran children learning in science berbasis budaya penyelidikan terdapat beberapa pedoman untuk berbagai macam aspek dalam kelas penyelidikan yaitu cara menggunakan pembelajaran kolaboratif dalam ruang kelas, cara memakai buku catatan sains dalam ruang kelas, cara membantu siswa membuat arti dari apa yang siswa baca, cara meningkatkan percakapan ilmiah antar siswa.

Model pembelajaran children learning in science berbasis budaya penyelidikan memberikan kesempatan untuk menumbuhkembangkan kemampuan penyelidikan dalam proses pembelajaran. Siswa terlibat langsung selama proses pembelajaran, siswa juga dibiasakan mandiri dalam memecahkan suatu masalah yang diberikan oleh guru.

Berdasarkan uraian tersebut, maka diadakan penelitian dengan judul Pengaruh Model Pembelajaran Children Learning in Science Berbasis Budaya Penyelidikan terhadap Kompetensi Pengetahuan IPA Siswa Kelas V SD Gugus Srikandi Denpasar Timur. Pelaksanaan penelitian ini bertujuan untuk mengetahui pengaruh model pembelajaran children learning in science berbasis budaya penyelidikan terhadap kompetensi pengetahuan IPA siswa kelas V SD Gugus Srikandi Denpasar Timur tahun pelajaran 2016/2017. 


\section{Metode Penelitian}

Penelitian yang dilaksanakan ini adalah tipe penelitian kuantitatif, yaitu penelitian eksperimen dengan menggunakan desain eksperimen semu (quasy experimental design). Hal ini dikarenakan karena tidak semua variabel yang muncul dalam kondisi eksperimen dapat diatur dan dikontrol secara ketat. Sugiyono (2014) memaparkan bahwa desain eksperimen semu (quasy experimental design) mempunyai kelompok kontrol tetapi tidak dapat berfungsi sepenuhnya untuk mengontrol variabel - variabel luar yang memengaruhi pelaksanaan eksperimen. Bentuk desain eksperimen semu yang digunakan dalam penelitian ini adalah non-equivalent control group design. Pemilihan desain ini dikarenakan tidak mungkin mengacak - acak kelas yang sudah terstruktur oleh sekolah. Dengan demikian, kelompok eksperimen dan kelompok kontrol yang digunakan sudah terbentuk tanpa adanya campur tangan peneliti. Peneliti tidak membentuk kelas baru dalam penelitian ini. Berdasarkan desain eksperimen semu dengan bentuk non-equivalent control group design, maka hanya diperhitungkan nilai post test tanpa memperhitungkan nilai pre test karena tujuan dilakukan penelitian ini hanya untuk mengetahui perbedaan bukan peningkatan kompetensi pengetahuan IPA pada kelompok eksperimen yang diberikan perlakuan (treatment) dengan kelompok kontrol yang tidak diberikan perlakuan (treatment). Dantes (2012) menyatakan bahwa pemberian pre test biasanya digunakan untuk mengukur ekuivalensi atau penyetaraan kelompok. Selanjutnya, post test digunakan untuk mendapatkan data kompetensi pengetahuan IPA dari kelompok eksperimen dan kelompok kontrol.

Langkah - langkah yang ditempuh dalam penelitian ini terdiri dari tiga tahap, yaitu tahap persiapan, pelaksanaan, dan akhir eksperimen. Pada tahap persiapan eksperimen kegiatan yang dilakukan yaitu, (1) menyusun RPP dan mempersiapkan media serta sumber belajar yang nantinya digunakan selama pembelajaran, (2) menyusun dan mengonsultasikan instrumen penelitian berupa tes kompetensi pengetahuan IPA yaitu tes objektif tipe pilihan ganda biasa (PGB) bersama guru kelas dan dosen pembimbing, (3) melakukan uji coba instrumen penelitian, (4) menentukan sampel penelitian dari populasi yang tersedia dengan cara random sampling teknik undian, (5) memberikan pre test kepada dua kelas yaang terpilih sebagai sampel penelitian untuk membuktikan kesetaraan, (6) menganalisis data hasil pre test dengan menggunakan uji-t, (7) menentukan kelompok eksperimen dan kelompok kontrol melalui pengundian. Pada tahap pelaksanaan eksperimen ini, kegiatan yang dilakukan yaitu, (1) memberikan perlakuan kepada kelompok eksperimen berupa model pembelajaran children learning in science berbasis budaya penyelidikan dan kelompok kontrol tidak dibelajarkan melalui model pembelajaran children learning in science berbasis budaya penyelidikan, (2) memberikan perlakuan sebanyak 6 kali di kelompok eksperimen dan 6 kali di kelompok kontrol oleh guru, (3) memberikan post test untuk kelompok eksperimen dan kelompok kontrol. Pada tahap akhir eksperimen kegiatan yang dilaksanakan yaitu, (1) menganalisis data hasil penelitian, dan (2) melakukan uji hipotesis.

Populasi merupakan suatu subjek penelitian yang memiliki peranan penting dalam suatu penelitian. populasi juga merupakan "keseluruhan objek dalam suatu penelitian" (Agung, 2014:69). Populasi pada prinsipnya adalah "semua anggota kelompok manusia, binatang, peristiwa, atau benda yang tinggal bersama dalam satu tempat dan secara terencana menjadi target kesimpulan dari hasil akhir suatu penelitian" (Sukardi, 2012:53). Populasi dalam penelitian ini adalah seluruh siswa kelas V di SD Gugus Srikandi Denpasar Timur tahun pelajaran 2016/2017 yang terdiri dari 344 siswa. Informasi yang diperoleh melalui wawancara dengan Ketua Gugus Srikandi, Kepala Sekolah dan beberapa guru kelas V di masing - masing SD Gugus Srikandi Denpasar Timur tahun pelajaran 2016/2017 mengenai keadaan siswa kelas V secara akademik bahwa nilai rata - rata siswa tidak jauh berbeda, kemampuan siswa yang memiliki kemampuan tinggi, sedang, dan rendah tersebar secara merata. Dengan demikian, tidak terdapat kelas unggulan maupun kelas non unggulan di SD Gugus Srikandi Denpasar Timur tahun pelajaran 2016/2017.

Sampel penelitian adalah bagian dari populasi yang bersifat representatif dalam suatu penelitian. "Sampel adalah sebagai bagian dari populasi, sebagai contoh yang diambil dengan menggunakan cara - cara tertentu" (Sumarni, 2012:110).

Pemilihan sampel dalam penelitian ini tidak dapat dilakukan pengacakan individu karena tidak dapat mengubah kelas yang terbentuk sebelumnya dan kelas $\mathrm{V}$ yang akan dijadikan sampel berada di sekolah berbeda. Dengan demikian, kelas yang dipilih sebagaimana telah terbentuk tanpa adanya campur tangan peneliti dan tidak dilakukan pengacakan individu dengan tujuan untuk mencegah kemungkinan subjek mengetahui dirinya dilibatkan dalam penelitian, sehingga penelitian ini benar-benar menggambarkan pengaruh perlakuan yang diberikan.

Teknik pengambilan sampel yang dilakukan dalam penelitian ini adalah teknik random sampling yaitu dengan mengacak kelas bukan siswa. Teknik random sampling yang digunakan mengakibatkan setiap kelas memperoleh hak atau kesempatan yang sama dipilih menjadi sampel penelitian. Pengambilan sampel dengan 
teknik random sampling dalam penelitian ini dilakukan dengan cara tradisional yaitu diundi. Selanjutnya, dua kelas yang terpilih diberikan pre test untuk diuji kesetaraannya menggunakan uji-t. Uji prasyarat yang meliputi uji normalitas dan homogenitas varians dilakukan terlebih dahulu sebelum dilakukan uji-t. Setelah kedua kelas dinyatakan setara, kedua kelas kemudian diundi kembali untuk menentukan kelompok eksperimen dan kelompok kontrol. Dari hasil pengundian terpilih kelas VA SD Negeri 13 Kesiman sebagai kelompok eksperimen dan kelas V SD Negeri 8 Sumerta sebagai kelompok kontrol.

Metode yang digunakan dalam penelitian ini adalah metode atau teknik tes. Tujuan metode tes adalah untuk mengetahui tingkat keberhasilan proses pembelajaran yang telah dilaksanakan. Data tes yang dikumpulkan dalam penelitian ini adalah data tes kompetensi pengetahuan IPA siswa kelas V SD Gugus Srikandi Denpasar Timur tahun pelajaran 2016/2017 yang menjadi anggota sampel. Jenis tes yang digunakan dalam penelitian ini adalah tes objektif tipe pilihan ganda biasa (PGB) dengan empat opsi (pilihan jawaban) dan satu opsi diantara empat opsi tersebut merupakan jawaban yang tepat. Tipe tes pilihan ganda dipilih karena memiliki beberapa kelebihan yaitu, (1) cara penilaian dapat dilakukan dengan mudah, cepat, dan objektif, (2) kemungkinan siswa menjawab dengan terkaan dapat dikurangi, (3) dapat digunakan untuk menilai kemampuan siswa dalam berbagai jenjang kemampuan kognitif, (4) dapat digunakan berulang-ulang, (5) sangat cocok untuk jumlah peserta tes yang banyak (Arifin, 2014). Penskoran tes tipe pilihan ganda biasa adalah 0 (nol) untuk butir tes yang dijawab salah dan 1 (satu) untuk butir tes yang dijawab dengan benar (jawaban dicocokkan dengan kunci jawaban). Hal ini sesuai dengan pendapat yang dikemukakan oleh Arifin (2014:135) yang menyatakan bahwa "tes objektif sering juga disebut tes dikotomi (dichotomously scored item) karena jawabannya antara benar atau salah dan skornya antara 1 atau 0". Skor 1 diberikan untuk jawaban benar pada setiap butir soal dan skor 0 untuk jawaban salah pada setiap butir soal. Tes objektif tipe pilihan ganda biasa yang digunakan bersifat terstandar karena telah dilakukan pengujian instrumen yaitu uji validitas, daya beda, indeks kesukaran dan reliabilitas. Dari hasil pengujian instrumen diperoleh 28 butir tes yang layak digunakan dalam penelitian dari total 40 butir tes yang telah diujicobakan. Teknik analisis data yang digunakan adalah statistik deskriptif dan statistik inferensial dengan uji-t.

\section{Hasil dan Pembahasan}

Data hasil kompetensi pengetahuan IPA diperoleh dari hasil post test yang diberikan setelah 6 kali pertemuan baik di kelompok eksperimen maupun di kelompok kontrol. Hasil post test kompetensi pengetahuan IPA kelompok eksperimen dan kelompok kontrol pada tema 8 ekosistem dapat dilihat pada tabel 1 berikut ini.

Tabel 1. Rekapitulasi Data Hasil Post Test Kompetensi Pengetahuan IPA

\begin{tabular}{ccc}
\hline Statistik & Kelompok Eksperimen & Kelompok Kontrol \\
\hline Mean & 80,51 & 71,03 \\
Varians & 107,19 & 85,54 \\
Standar Deviasi & 10,35 & 9,24 \\
Nilai Minimum & 57 & 54 \\
Nilai Maksimum & 100 & 93
\end{tabular}


Berdasarkan tabel 1, diketahui bahwa siswa kelompok eksperimen memperoleh nilai rata - rata/mean 80,51 dan rata - rata persentase kompetensi pengetahuan IPA yang diperoleh adalah $80,51 \%$. Rata - rata persentase kompetensi pengetahuan IPA tersebut kemudian dikategorikan dengan tabel konversi PAP dan berada pada kategori tinggi. Sedangkan siswa kelompok kontrol memperoleh nilai rata - rata/mean 71,03 dan rata - rata persentase kompetensi pengetahuan IPA yang diperoleh adalah $71,03 \%$. Rata - rata persentase kompetensi pengetahuan IPA tersebut kemudian dikategorikan dengan tabel konversi PAP dan berada pada kategori sedang.

Setelah dilakukan analisis statistik deskriptif, dilanjutkan dengan analisis statistik inferensial. Uji prayarat dilakukan terlebih dahulu sebelum menuju uji hipotesis. Uji prasyarat meliputi uji normalitas dan uji homogenitas varians. Uji normalitas ini dilakukan untuk membuktikan bahwa kedua sampel tersebut berdistribusi normal. Ringkasan hasil uji normalitas tersaji pada tabel 2 berikut ini.

Tabel 2. Rekapitulasi Hasil Uji Normalitas Sampel Penelitian

\begin{tabular}{clcccc}
\hline No. & \multicolumn{1}{c}{ Sampel } & $\mathrm{n}$ & $\chi^{2}$ hitung & $\chi^{2}$ tabel & Keterangan \\
\hline 1. & Kelompok Eksperimen & 35 & 2,76 & 11,07 & Berdistribusi normal \\
2. & Kelompok Kontrol & 34 & 6,51 & 11,07 & Berdistribusi normal
\end{tabular}

Berdasarkan hasil uji normalitas kelompok eksperimen, diperoleh $\chi^{2}$ hitung $=2,76$ kemudian nilai tersebut dibandingkan dengan $\chi_{\text {tabel }}^{2}=11,07$. Hal ini menunjukkan bahwa $\chi^{2}$ hitung $\leq \chi_{\text {tabel }}^{2}$, berarti data hasil kompetensi pengetahuan IPA kelompok eksperimen berdistribusi normal. Selanjutnya hasil uji normalitas kelompok kontrol, diperoleh $\chi^{2}$ hitung $=6,51$ kemudian nilai tersebut dibandingkan dengan $\chi_{\text {tabel }}^{2}=11,07$. Hal ini menunjukkan bahwa $\chi^{2}$ hitung $\leq \chi_{\text {tabel }}^{2}$, berarti data hasil kompetensi pengetahuan IPA kelompok kontrol berdistribusi normal.

Uji homogenitas varians dalam penelitian ini dilakukan dengan uji F. Kriteria pengujian jika $F_{\text {hitung }}<$ $F_{\text {tabel }}$ maka sampel homogen. Pengujian dilakukan pada taraf signifikansi 5\% dengan derajat kebebasan untuk pembilang $\mathrm{n}_{1}-1(35-1=34)$ dan derajat kebebasan untuk penyebut $\mathrm{n}_{2}-1(34-1=33)$ adalah 1,80 dan hasil analisis $F_{\text {hitung }}=1,25$, karena $F_{\text {hitung }}<F_{\text {tabel, }}$, sehingga data kedua kelompok memiliki varians homogen.

Setelah uji prasyarat terpenuhi dengan data berdistribusi normal dan homogen, selanjutnya dilakukan uji hipotesis dengan menggunakan uji-t dengan polled varians (jumlah sampel tidak sama $(\mathrm{n} 1 \neq \mathrm{n} 2)$ ). Hipotesis yang diuji dalam penelitian ini adalah tidak terdapat perbedaan yang signifikan kompetensi pengetahuan IPA kelompok siswa yang dibelajarkan melalui model pembelajaran children learning in science berbasis budaya penyelidikan dan kelompok siswa yang tidak dibelajarkan melalui model pembelajaran children learning in science berbasis budaya penyelidikan pada kelas V SD Gugus Srikandi Denpasar Timur tahun pelajaran $2016 / 2017$. Berdasarkan hasil perhitungan uji-t diperoleh $t_{\text {hitung }}=3,95$ dengan derajat kebebasan $\mathrm{dk}=\mathrm{n} 1+\mathrm{n} 2$ $-2=35+34-2=67$ taraf signifikansi $5 \%$ diperoleh $t_{\text {tabel }}=2,00$. Dengan demikian, nilai $t_{\text {hitung }}>t_{\text {tabel }}$ yaitu 3,95 > 2,00 sehingga $\mathrm{H}_{\mathrm{o}}$ ditolak. Rekapitulasi hasil analisis uji-t kelompok sampel penelitian ini disajikan dalam tabel berikut ini.

Tabel 3. Rekapitulasi Hasil Analisis Uji-t Kelompok Sampel Penelitian

\begin{tabular}{llcccccc}
\hline No. & Kelompok Sampel & $\mathrm{n}$ & $\mathrm{dk}$ & Varians & $\bar{X}$ & thitung & $\mathrm{t}_{\text {tabel }}$ \\
\hline 1. & Eksperimen & 35 & 67 & 107,19 & 80,51 & 3,95 & 2,00 \\
2. & Kontrol & 34 & & 85,54 & 71,03 & & \\
\hline
\end{tabular}

Berdasarkan hasil analisis uji-t kelompok sampel penelitian, didapatkan $t_{\text {hitung }}>t_{\text {tabel }}$ yaitu 3,95 $>2,00$. Dengan demikian, maka $\mathrm{H}_{\mathrm{o}}$ ditolak dan $\mathrm{H}_{\mathrm{a}}$ diterima. Hal ini berarti terdapat perbedaan yang signifikan kompetensi pengetahuan IPA kelompok siswa yang dibelajarkan melalui model pembelajaran children learning in science berbasis budaya penyelidikan dan kelompok siswa yang tidak dibelajarkan melalui model pembelajaran children learning in science berbasis budaya penyelidikan pada kelas V SD Gugus Srikandi Denpasar Timur tahun pelajaran 2016/2017. Selain itu, berdasarkan hasil penelitian nilai rata - rata/mean kompetensi pengetahuan IPA kelompok eksperimen lebih dari kelompok kontrol yakni $(80,51>71,03)$, hal ini berarti terdapat pengaruh kompetensi pengetahuan IPA kelompok siswa yang dibelajarkan melalui model pembelajaran children learning in science berbasis budaya penyelidikan dan kelompok siswa yang tidak dibelajarkan melalui model pembelajaran children learning in science berbasis budaya penyelidikan pada siswa kelas V SD Gugus Srikandi Denpasar Timur tahun pelajaran 2016/2017. 
Perbedaan hasil kompetensi pengetahuan IPA yang signifikan antara kelompok siswa yang dibelajarkan melalui model pembelajaran children learning in science berbasis budaya penyelidikan dan kelompok siswa yang tidak dibelajarkan melalui model pembelajaran children learning in science berbasis budaya penyelidikan disebabkan adanya perbedaan perlakuan pada saat kegiatan pembelajaran berlangsung. Pembelajaran dengan menggunakan model pembelajaran children learning in science berbasis budaya penyelidikan mendorong siswa untuk mampu memahami, menemukan dan merekonstruksi konsep yang sedang dipelajari dan didasarkan pada pengembangan cara menyelidiki agar pembelajaran menjadi bermakna. Siswa juga dituntut aktif dalam kegiatan pembelajaran yang dimulai dari tahap awal yaitu orientasi (orientation), pemunculan gagasan (elicitation of ideas), penyusunan ulang gagasan (restructuring of ideas), penerapan gagasan (application of ideas), dan pemantapan gagasan (review change in ideas). Langkah penyusunan ulang gagasan (restructuring of ideas) masih dibedakan atas tiga bagian, yaitu pengungkapan dan pertukaran gagasan (clarification and exchange), pembukaan pada situasi konflik (exposure to conflict situation), dan konstruksi gagasan baru dan evaluasi (construction of new ideas and evaluation). Berdasarkan tahapan - tahapan pembelajaran dengan menggunakan model pembelajaran children learning in science berbasis budaya penyelidikan, keunggulannya adalah siswa menjadi lebih aktif dalam menyampaikan gagasan serta bekerjasama dalam memecahkan masalah. Pembelajaran menjadi lebih bermakna karena siswa diajak untuk melakukan kegiatan percobaan atau observasi. Memberi kesempatan untuk melibatkan siswa yang tertarik pada penelitian ilmiah, mempertajam kemampuan berpikir kritis, dan meningkatkan kesadaran akan pentingnya riset mendasar.

Pada kelompok kontrol pembelajaran yang biasa dilaksanakan yakni pembelajaran dengan menerapkan pendekatan saintifik. Pembelajaran pada kelompok eksperimen dan kelompok kontrol sama - sama menerapkan pendekatan saintifik, karena penerapan pendekatan saintifik dalam proses pembelajaran merupakan ciri esensial dari kurikulum 2013. Tetapi yang membedakan di kelas eksperimen menggunakan model pembelajaran children learning in science berbasis budaya penyelidikan yang menjadikan pembelajaran lebih menyenangkan. Sedangkan pada kelompok kontrol yang menerapkan pembelajaran dengan pendekatan saintifik tanpa dipadukan dengan model pembelajaran yang lain. Hal tersebut dapat membuat siswa merasa kurang bersemangat karena terasa monoton.

Hasil penelitian ini memperkuat simpulan yang disampaikan oleh Budiarti (2014) yang menyatakan bahwa model pembelajaran CLIS berpengaruh terhadap hasil belajar IPA siswa kelas IV di Gugus III Kecamatan Busungbiu, Kabupaten Buleleng pada tahun pelajaran 2013/2014. Penelitian yang dilaksanakan oleh Budiarti hanya menerapkan model pembelajaran children learning in science (CLIS) sedangkan pada penelitian ini divariasikan dengan budaya penyelidikan.

Berdasarkan paparan tersebut dapat dsimpulkan bahwa model pembelajaran children learning in science berbasis budaya penyelidikan berpengaruh terhadap kompetensi pengetahuan IPA siswa kelas V SD Gugus Srikandi Denpasar Timur tahun pelajaran 2016/2017. Pelaksanaan pembelajaran dengan menggunakan model pembelajaran children learning in science berbasis budaya penyelidikan dapat menjadi alternatif untuk berinovasi pada muatan materi IPA serta mampu mengefektifkan sekaligus mengefisienkan kegiatan pembelajaran di SD.

Beberapa faktor yang perlu diperhatikan berkaitan dengan pelaksanaan model pembelajaran children learning in science berbasis budaya penyelidikan adalah menciptakan pembelajaran yang bermakna, merekonstruksi konsep yang sedang dipelajari, memberikan kebebasan pada siswa dalam mengembangkan ide atau gagasan, meningkatkan kesadaran akan pentingnya riset mendasar dan memberikan kesempatan pada siswa untuk bertanya secara bebas dengan teman maupun guru pada saat kegiatan pembelajaran berlangsung.

\section{Simpulan dan Saran}

Berdasarkan hasil analisis dengan uji-t, diperoleh $t_{\text {hitung }}>t_{\text {tabel }}$ yaitu 3,95 $>2,00$. Dengan demikian $\mathrm{H}_{\mathrm{o}}$ yang menyatakan bahwa tidak terdapat perbedaan yang signifikan kompetensi pengetahuan IPA kelompok siswa yang dibelajarkan melalui model pembelajaran children learning in science berbasis budaya penyelidikan dan kelompok siswa yang tidak dibelajarkan melalui model pembelajaran children learning in science berbasis budaya penyelidikan pada kelas V SD Gugus Srikandi Denpasar Timur tahun pelajaran 2016/2017 ditolak. Selain itu, berdasarkan hasil penelitian nilai rata - rata/mean kompetensi pengetahuan IPA kelompok eksperimen lebih dari kelompok kontrol yakni $(80,51>71,03)$. Hal ini berarti terdapat perbedaan yang signifikan kompetensi pengetahuan IPA kelompok siswa yang dibelajarkan melalui model pembelajaran children learning in science berbasis budaya penyelidikan dan kelompok siswa yang tidak dibelajarkan melalui 
model pembelajaran children learning in science berbasis budaya penyelidikan pada kelas V SD Gugus Srikandi Denpasar Timur tahun pelajaran 2016/2017. Jadi, dapat dsimpulkan bahwa model pembelajaran children learning in science berbasis budaya penyelidikan berpengaruh terhadap kompetensi pengetahuan IPA siswa kelas V SD Gugus Srikandi Denpasar Timur tahun pelajaran 2016/2017.

Memperhatikan simpulan tersebut, maka saran yang dapat disampaikan adalah sebagai berikut. (1) guru hendaknya lebih inovatif dalam membelajarkan siswa, menambah wawasan mengenai model - model pembelajaran sehingga dapat menciptakan pembelajaran yang bermakna yang berkontribusi lebih baik terhadap hasil kompetensi pengetahuan IPA siswa (2) kepala sekolah hendaknya dapat menciptakan kondisi yang mampu mendorong guru untuk mencoba menerapkan berbagai model pembelajaran yang inovatif (3) peneliti lain diharapkan dapat menjadikan penelitian ini sebagai referensi untuk melaksanakan penelitian berikutnya atau menemukan inovasi model pembelajaran yang lain sehingga siswa bersemangat dan antusias untuk mengikuti proses pembelajaran.

\section{Daftar Pustaka}

Agung, A.A Gede. 2014. Metodologi Penelitian Pendidikan. Singaraja: Aditya Media Publishing. Arifin, Zainal. 2014. Evaluasi Pembelajaran Prinsip, Teknik, Prosedur. Bandung: PT Remaja Rosdakarya. Budiarti, Luh Putu Yudha. 2014. "Pengaruh Model Pembelajaran CLIS terhadap Hasil Belajar IPA Siswa Kelas IV SD di Gugus III Kecamatan Busungbiu”. Jurnal Mimbar PGSD Universitas Pendidikan Ganesha Jurusan PGSD, Volume 2, Nomor 1.

Dantes, Nyoman. 2012. Metode Penelitian. Yogyakarta: C.V Andi Offset.

Kurniasih, Imas dan Berlin Sani. 2014. Sukses Mengimplementasikan Kurikulum 2013 Memahami Berbagai Aspek Dalam Kurikulum 2013. Jakarta: Kata Pena.

Nalasari, Kd Anggi. 2016. "Penerapan Inkuiri Terbimbing dalam Pendekatan Saintifik Berbasis Budaya Penyelidikan untuk Meningkatkan Keaktifan dan Pengetahuan IPA". e - Journal PGSD Universitas Pendidikan Ganesha Jurusan PGSD, Volume 4, Nomor 1 (hlm. 3).

National Science Teachers Association. 2009. The Biology Teacher's Handbook 4th Edition. Terjemahan Bambang Sarwiji. Buku Pedoman Guru Biologi Edisi ke-4. 2013.Cetakan I. Jakarta: PT Indeks.

Samatowa, Usman. 2016. Pembelajaran IPA di Sekolah Dasar. Jakarta: PT Indeks.

Sugiyono. 2014. Metode Penelitian Pendidikan (Pendekatan Kuantitatif, Kualitatif, dan R\&D). Bandung: Alfabeta.

Sukardi. 2012. Metodologi Penelitian Pendidikan. Jakarta: PT Bumi Aksara.

Sumarni, Sri.2012.Metodelogi Penelitian Pendidikan. Yogyakarta: Insan Madani.

Susanto, Ahmad. 2013. Teori Belajar dan Pembelajaran di Sekolah Dasar. Jakarta: Kencana Prenadamedia Group.

Undang - Undang Republik Indonesia Nomor 20 Tahun 2003 tentang Sistem Pendidikan Nasional. Jakarta: Departemen Pendidikan Nasional.

Wisudawati, Asih Widi dan Eka Sulistyowati. 2015. Metodologi Pembelajaran IPA. Jakarta: Bumi Aksara. 